\title{
RETRACTED ARTICLE: Economic Boom or Environmental Doom: E-waste Scavenging as a Livelihood Strategy among the Youth in Accra, Ghana
}

\section{Martin Oteng-Ababio}

Published online: 16 September 2011

(C) Springer Science+Business Media B.V. 2011

This article has been retracted due to copyright issues that cannot be resolved.

This article has been retracted due to copyright issues that cannot be resolved.

M. Oteng-Ababio ( $\bowtie)$

Urban Disaster Risk Reduction Programme, Department of Geography and Resource Development, University of Ghana, Box LG 59, Legon, Accra, Ghana e-mail:moababio@yahoo.com 